\title{
PERLINDUNGAN TERHADAP KONSUMEN YANG TIDAK MENDAPATKAN SERTIFIKAT HAK MILIK SATUAN RUMAH SUSUN
}

\author{
Galih Husain Fauzi \\ Mahasiswa Program S1 Fakultas Hukum Universitas Tarumanagara Jakarta \\ (E-mail : Galihhusain@gmail.com)
}

Ermanto Fahamsyah

(Corresponding Author)

(Dosen Fakultas Hukum Univesitas Jember, Meraih Sarjana Hukum dari Fakultas Hukum Universitas Jember (2002), Magister Hukum dari Fakultas Hukum Universitas Indonesia (2008), Doktor Ilmu

Hukum dari Fakultas Hukum Universitas Indonesia (2013)

(Email : ermanto_fahamsyah@yahoo.co.id)

\begin{abstract}
Indonesia is one of the countries that has large population. Development of public housing is tended in order that every family can occupy a public housing that is proper in healthful, secure, harmonious, and uniformed environment. The proper public house is a house construction that is fulfill safety regulation in its construction, suffice the minimum construction area, and give health for public house occupant. Realize of the statements, is needed for developing a construction public housing that can be occupied together in a public house building,that is devided in some parts separately, on vertical ar horizontal for every occupation. There is a lot of participants that is involved in developing a public house building, that is the developer as a participant for developing a public house building, owner, and the occupant as an organizer. The public house building certificate will be proven with a freehold public house building certificate for every occupant that is already fulfill the regulations as an owner in the public house building. Researcher has taken one of the case studies about the restraining of a freehold of public house building, with purpose of the case study is knowing a consumer protection legally toward the participant developer that is restraing a freehold public house building. Researcher solved this case study using the normative method that is supported an interview with related parties. Based on the research will be knowing that the regulation of a freehold public house building certificate does not applied clearly on the sanction of participant developer that is restraining a freehold public house building certificate on the time that is determined.
\end{abstract}

Keywords: Consumer Protection, Liability, certificate of ownership of apartment units. 


\section{Pendahuluan}

\section{A. Latar Belakang}

Negara Indonesia merupakan salah satu negara yang memiliki kepadatan penduduk yang cukup padat. Salah satu tujuan dibentuknya negara Republik Indonesia ialah memajukan kesejahteraan umum. Untuk memajukan kesejahteraan umum dilaksanakan pembangunan nasional, yang hakikatnya yaitu pembangunan manusia Indonesia seutuhnya dan pembangunan seluruh rakyat Indonesia yang menekankan pada keseimbangan pembangunan kemakmuran lahiriah dan kepuasan batiniah.

Setiap manusia dihadapkan pada 3 (tiga) kebutuhan dasar yaitu pangan, sandang, dan papan. Papan merupakan salah satu kebutuhan primer manusia yang paling utama yaitu membuat tempat tinggal. Kebutuhan akan rumah sebagai tempat tinggal atau hunian membutuhkan tanah sebagai media untuk mewujudkan rumah tersebut. Tanah merupakan salah satu sumber daya alam yang sangat penting bagi manusia, baik dalam fungsinya sebagai sarana untuk mencari penghidupan diberbagai bidang dan digunakan sebagai tempat untuk bermukim dengan didirikan perumahan sebagai tempat tinggal. Tanah merupakan salah satu modal pokok dan unsur yang utama dalam pembangunan.

Perumahan dan permukiman sebagai kebutuhan dasar manusia sangat berpengaruh dalam pembentukan kepribadian bangsa. Perumahan dan permukiman tidak hanya dapat dilihat sebagai sarana kebutuhan hidup, tetapi lebih dari itu merupakan proses bermukim manusia. Hal ini sebagaimana telah diatur dalam Pasal 28H Ayat (1) Undang-Undang Dasar Negara Republik Indonesia Tahun 1945 (selanjutnya disebut UUD 1945) yang menyatakan bahwa "Setiap orang berhak hidup sejahtera lahir dan batin, bertempat tinggal, dan mendapat lingkungan hidup yang baik dan sehat serta berhak memperoleh layanan kesehata"1 Kebutuhan tersebut wajib dihormati, dilindungi, ditegakan, dan dimajukan oleh pemerintah. ${ }^{2}$ Selanjutnya mengenai hal ini diatur pula lebih lanjut dalam Pasal 40 Undang-Undang Nomor 39 Tahun 1999 Tentang

\footnotetext{
1) Indonesia, Undang-Undang Dasar Negara Republik Indonesia Tahun 1945, Pasal 28 Ayat 1.

2) Rosmidi, Mimi dan Imam Koeswahyono, Konsepsi Hak milik atas Satuan Rumah Susun dalm Hukum Agraria, (Malang: Setara Press, 2010, hal.12.
} 
Hak Asasi Manusia (selanjutnya disebut Undang-Undang HAM) yang mengatakan bahwa "Setiap orang berhak untuk bertempat tinggal serta berkehidupan yang layak". 3

Pembangunan perumahan ditujukan agar setiap keluarga menempati rumah yang layak dalam lingkungan yang sehat, aman, serasi dan teratur. Rumah yang layak adalah bangunan rumah yang sekurang-kurangnya memenuhi persyaratan keselamatan bangunan dan kecukupan minimum luas bangunan serta kesehatan penghuninya. Seiring dengan meningkatnya jumlah penduduk, maka penyelenggaraan pembangunan akan meningkat dan kebutuhan akan tanah akan semakin meningkat. ${ }^{4}$ Belum lagi di tambah banyaknya masyarakat luar daerah yang berbondong-bondong pindah ke kotakota besar. Mereka bertujuan untuk mendapatkan penghasilan yang lebih besar di bandingkan dengan kota mereka berasal.

Menyadari kenyataan tersebut, perlu kiranya dikembangkan suatu konsep Pembangunan Perumahan yang dapat dihuni secara bersama-sama dalam suatu bangunan bertingkat, yang dibagi-bagi atas bagian-bagian secara terpisah, baik vertikal atau horizontal untuk masing-masing penghuni. ${ }^{5}$ Menurut Arie Sukanti Hutagalung bahwa dengan demikian dikota-kota besar perlu diarahkan pembangunan perumahan dan pemukiman yang terutama sepenuhnya pada pembangunan Rumah Susun.

Pembangunan Rumah Susun bertujuan untuk memenuhi kebutuhan perumahan yang layak bagi rakyat, dengan meningkatkan daya guna dan hasil guna tanah di daerah-daerah yang berpendudukan padat dan hanya tersedia luas tanah yang terbatas. Dalam pembangunannya diperhatikan antara lain kepastian hukum dalam penguasaan dan keamanan dalam pemanfaatan, kelestarian sumber daya alam yang bersangkutan serta penciptaan lingkungan permukiman yang nyaman, lengkap, serasi, dan seimbang. ${ }^{6}$

\footnotetext{
3) Indonesia, Undang-Undang Nomor 39 Tahun 1999 tentang Hak Asasi Manusia (Tambahan Lembaran Negara Republik Indonesia Nomor 3886), Pasal 40.

4) Sarkawi, Hukum Pembebasan Tanah Milik Adat Untuk Pembangunan Kepentingan Umum, Cetakan Ke-1. (Yogyakarta: Graha Ilmu, 2014), hal.14.

5) Badan Pertanahan Nasional, Himpunan Karya Tulis Pendaftaran Tanah, (Jakarta, 1989). hal. 60.

6) Boedhi Harsono, Hukum Agraria Indonesia, Cetakan ke-9. (Jakarta: Djambatan, 2003). hal 358.
} 
Seiring berjalan waktu, pembangunan rumah susun semakin bermunculan dan meningkat karena lokasi rumah susun yang dibangun berada dekat dengan lokasi perkantoran, sehingga masyarakat merasakan kebutuhan akan hunian rumah susun tersebut, terutama dangan semakin meningkatnya kemacetan lalu lintas. Saat ini hampir di seluruh kota besar Indonesia sudah dibangun rumah susun.

Perlu di ketahui bahwa, yang dimaksud dengan rumah susun bukan hanya rumah susun yang diperuntukan untuk masyarakat berpenghasilan rendah (MBR) seperti yang selama ini kita ketahui. Berdasarkan Undang-undang Republik Indonesia Nomor 20 Tahun 2011 tentang Rumah Susun Pasal 1 angka 1 yang dimaksud dengan rumah susun adalah bangunan gedung bertingkat yang dibangun dalam suatu lingkungan yang terbagi dalam bagianbagian yang distrukturkan secara fungsional, baik dalam arah horizontal maupun vertikal dan merupakan satuan-satuan yang masing-masing dapat dimiliki dan digunakan secara terpisah, terutama untuk tempat hunian yang dilengkapi dengan bagian bersama, benda bersama, dan tanah bersama. ${ }^{7}$

Terdapat banyak pihak yang terlibat dalam penyelenggaraan rumah susun yaitu pelaku pembangunan (pengembang) sebagai pembangun rumah susun, pemilik, dan penghuni sebagai pengelola. pemilik dan penghuni memliki suatu kelembagaan yang di sebut Perhimpunan Pemilik dan Penghuni Satuan Rumah Susun (selanjutnya di sebut PPPSRS). PPPSRS adalah badan hukum yang beranggotakan para pemilik atau penguhi satuan rumah susun. Bersdasarkan Pasal 74 Ayat (3) Undang-Undang Rumah Susun, PPPSRS diberi kedudukan sebagai badan hukum berdasarkan undang-undang ini.

Dalam UU Rumah Susun Pasal 46 terdapat pengaturan tentang Hak Milik atas Satuan Rumah Susun yang menyatakan bahwa:

1. hak kepemilikan atas sarusun merupakan hak milik yang bersifat perseorangan yang terpisah dengan hak bersama atas bagian bersama, benda bersama, dan tanah bersama.

7) Indonesia, Undang-Undang Nomor 20 Tahun 2011 tentang Rumah Susun. (Lembaran Negara Republik Indonesia Nomor 108). Pasal 1 angka (1). 
2. Hak atas bagian bersama, benda bersama, dan tanah bersama sebagai mana dimaksud pada ayat (1) dihitung berdasarkan atas NPP.

Selain itu, kepemilikan atas satuan rumah susun dibuktikan dengan diterbitkan SHM sarusun bagi setiap orang yang telah memenuhi syarat sebagai pemegang hak atas tanah hal ini tercantum di Pasal 47 UndangUndang Rumah Susun.

Namun, pada kenyataan yang terjadi bahwa Rumah Susun komersial yang terletak di Cempaka Mas yaitu Apartement Graha Cempaka Mas, banyak diantaranya pemiliknya tersebut belum mendapatkan sertifikat hak milik satuan rumah susun (SHMSRS). Mereka yang tidak memiliki sertifikat hak milik satuan rumah susun hanya mempunyai Peraturan Pengikat Jual Beli (PPAJB) atau Akta Jual Beli (AJB) padahal sebenarnya mereka telah menempati apartement tersebut sudah lama, memenuhi segala syarat dan melunasi segala pembayaran yang telah ditetapkan.

Kemudian seharusnya setelah rumah susun dijual atau dibeli oleh konsumen maka atas bagian yang sudah dijual tersebut pihak pengembang sudah tidak dapat memilikinya. Sesuai dengan Undang-Undang Rumah Susun pada Pasal 75 Ayat (2) dalam hal PPPSRS telah terbentuk, pelaku pembangunan segera menyerahkan pengeloaan benda bersama, bagian bersama, dan tanah bersama kepada PPPSRS. Tetapi pada kenyataannya pelaku pembangunan tetap berkeinginan mengelola rumah susun yang identifikasikan dapat memperoleh keuntungan yang besar dari penglolaan tersebut. Seheingga terjadi keributan antara pemilik dan pengembang rumah susun tersebut yang berkepanjangan, sehingga terdapat dua PPPSRS yang berada dalam lingukang satuan rusun yang diantaranya PPPSRS yang dibentuk oleh pengembang dan PPPSRS yang di bentuk oleh para penghuni rumah susun tersebut, sebagaimana telah diatur dalam Pasal 59 Ayat (2) yang dimana mengatur mengenai masa transisi kewanangan PPPSRS yang awal dibentuk oleh pihak pengembang kemudian diberikan kepada pihak penghuni.

Dalam Rapat Umun Luar Biasa (kemudian disebut RULB) yang diikuti oleh pihak pengembang, pihak penghuni dan pihak pemerintah terkait telah menghasilkan keputusan dimana pihak pengembang harus memberikan 
sertifikat hak milik dan memberhentikan kepengurusan PPPSRS yang dibentuk oleh pihak pengembang. Tetapi pada kenyataannya pihak pengembang tidak menjalankan hasil dari keputusan rapat tersebut yang berdampak pada pihak penghuni yang masih belum mendapatkan SHM dan kepengurusan PPPSRS. Dalam kepemilikan satuan rumah susun pihak penghuni memiliki hak dan kewajiban yang harus dipenuhi, dimana hak dan kewajiban tersebut harus seimbang, baik dari sisi pengembang maupun dari penghuni itu sendiri. Tetapi pada kenyataannya setelah pihak penghuni telah melaksanakan kewajibannya, pihak pengembang tidak sepenuhnya melaksanakan kewajibannya yaitu, salah satunya tidak memberikan hak penghuni berupa SHMSRS yang seharusnya diberikan oleh pengembang, jika dikaitkan dengan Undang-Undang Nomor 8 Tahun 1999 tentang Perlindungan konsumen (selanjutnya disebut UUPK). Dalam ketentuan mengenai hak yang diatur pada Pasal 4 huruf (b) menyatakan bahwa "hak untuk memilih barang dan/atau jasa serta mendapatkan barang dan/atau jasa tersebut sesuai dengan nilai tukar dan kondisi serta jaminan yang dijanjikan"8 oleh karena itu dapat dikatakan bahwa hak yang dimiliki oleh penghuni tidak diberikan oleh pengembang sebagaimana yang telah diatur dalam ketentuan tersebut. Begitu juga dengan kewajiban yang telah diatur dalam UUPK Pasal 7 huruf (a) adalah "beritikad baik dalam melakukan kegiatan usahanya" 9 . Dengan demikian pengembang telah melanggar ketentuan tersebut, karena sejak serah terima apartemen graha cempaka mas yang telah dilakukan pada tanggal 22 desember 1999 sampai pada saat ini kurang lebih 18 tahun masih ada penghuni yang tidak menerima haknya berupa SHMSRS yang seharusnya sudah diberikan sama seperti para penghuni lainnya.

\section{B. Rumusan Masalah}

Berdasarkan apa yang telah diuraikan di atas, maka penulis mengambil pokok permaslahan yang hendak diteliti dalam permasalahan ini, yaitu :

\footnotetext{
${ }^{8)}$ Indonesia. Undang-undang Nomor 8 Tahun 1999 tentang perlindungan konsumen (Lembaran Negara Republik Indonesia Tahun 1999 Nomor 42, Tambahan Lembaran Negara Republik Indonesia Nomor 3821), Pasal 4.

9) Ibid., Pasal 7
} 
Apa bentuk perlindungan hukum terhadap konsumen yang tidak Sertifikat Hak Milik Satuan Rumah Susun?

\section{Metode Penelitian}

Penelitian hukum adalah suatu proses untuk menemukan aturan hukum, prinsip-prinsip hukum, maupun doktrin-doktrin hukum guna menjawab isu hukum yang dihadapi. ${ }^{10}$ Berdasarkan judul yang diangkat oleh Penulis, maka metode penelitian yang akan digunakan Penulis adalah sebagai berikut:

1. Tipe Penelitian

Tipe penelitian yang digunakan oleh Penulis adalah tipe penelitian hukum normatif. Alasan Penulis memilih metode ini dalam rangka mencari kebenaran koherensi adalah mendapatkan sesuatu yang secara aksiologis merupakan nilai atau ketetapan/aturan sebagai referensi untuk ditelaah. ${ }^{11}$

2. Jenis dan Sumber Penelitian Hukum

Teknik pengumpulan data yang digunakan dalam penelitian berupa bahan hukum primer dan bahan hukum sekunder serta bahan hokum tersier yang dikumpulkan melalui penelitian kepustakaan.

Jenis data yang digunakan dalam penelitian ini adalah data sekunder. Data sekunder yang dimaksud bersumber dari bahan pustaka. Sumber Penelitian berasal dari Data Sekunder yang berupa:

a. Bahan hukum primer yaitu bahan hukum mengikat, dalam hal ini adalah peraturan perundang-undangan dan ketentuan peraturan yang berkaitan dengan penulisan penelitian ini;

b. Bahan hukum sekunder yaitu bahan-bahan yang memberikan penjelasan bahan hukum primer, dalam hal ini adalah buku-buku hukum, makalah-makalah hukum, dan Artikel;

c. Bahan Hukum Tersier yakni bahan yang memberikan petunjuk maupun penjelasan terhadap bahan hukum primer dan sekunder. ${ }^{12}$

3. Pendekatan

\footnotetext{
${ }^{10)}$ Peter Mahmud Marzuki, Penelitian Hukum Edisi Revisi, Cetakan ke- 8, (Jakarta: Kencana Prenada Media Group, 2013), hal.35.

11) Ibid., hal.33.

${ }^{12}$ Soerjono Soekanto dan Sri Mamudji, Penelitian Hukum Normatif Suatu Tinjauan Singkat, (Jakarta: Raja Grafindo Persada, 2009), hal. 13.
} 
Dalam penelitian hukum normatif dikenal beberapa pendekatanpendekatan yaitu antara lain: ${ }^{13)}$

a. Pendekatan undang-undang (statute approach);

b. Pendekatan kasus (case approach);

c. Pendekatan historis (historical approach);

d. Pendekatan komparatif (comparative approach); dan

e. Pendekatan konseptual (conseptual approach);

Pendekatan yang akan digunakan dalam penelitian ini adalah pendekatan undang-undang (statute approach) dan konseptual (conseptual approach). Pendekatan undang-undang adalah pendekatan yang dilakukan dengan menelaah semua Undang-Undang maupun regulasi yang berkaitan dengan kasus yang dibahas dan pendekatan konseptual merupakan pendekatan yang beranjak dari pandangan-pandangan dan doktrin-doktrin di dalam ilmu hukum. ${ }^{14}$

Metode pendekatan ini dipilih karena dalam penelitian ini, Penulis melakukan telaah terhadap semua peraturan perundang-undangan dan doktrin-doktrin yang terkait dengan perlindungan hukum bagi konsumen terhadap konsumen atas pelaku pembangunan yang tidak memberikan setifikat hak milik satuan rumah susun. Spesifikasi penelitian yang digunakan adalah penelitian secara preskriptif yang pada bagian akhirnya berisi saran.

4. Teknik Pengumpulan Bahan Hukum

Teknik pengumpulan bahan hukum yang Penulis gunakan dalam penelitian ini adalah dengan tinjauan pustaka atau (library research). Pengumpulan bahan hukum dari bahan hukum sekunder yang berasal dari artikel-artkel di internet dan wawancara kepada narasumber.

5. Teknik Pengelolaan Bahan Hukum

Teknik pengolahan bahan hukum yang digunakan Penulis adalah pengolahan yang secara runtut dan sistematis sehingga memudahkan penulis melakukan analisis. Pengelolaan bahan hukum dilakukan secara

\footnotetext{
13) Ibid., hal.93.

${ }^{14)}$ Ibid., hal. 135.
} 
sistematis bertujuan untuk mendapatkan gambaran umum dari hasil penelitian.

6. Teknik Analisis Bahan Hukum

Teknik analisis bahan hukum yang Penulis gunakan dalam penelitian ini adalah dengan menggunakan metode analisis bahan hukum kualitatif, yaitu penelitian yang menekankan pada bahan-bahan hukum yang diperoleh dari berbagai sumber, seperti buku-buku, artikel, jurnal, serta peraturan perundang-undangan yang terkait.

\section{Pembahasan}

Negara Indonesia mempunyai tujuan untuk mewujudkan kesejahteraan umum dengan dilaksanakannya pembangunan nasional. Pembangunan nasional yang dimaksud adalah untuk mewujudkan kesejahteraan lahir dan batin bagi seluruh rakyat Indonesia secara adil dan merata berdasarkan Pancasila dan UndangUndang Dasar Negara Republik Indonesia Tahun 1945. Salah satu unsur pokok kesejahteraan rakyat adalah terpenuhinya kebutuhan akan perumahan yang merupakan kebutuhan dasar bagi setiap warga Negara Indonesia dan keluarganya sesuai dengan harkat dan martabatnya sebagai manusia.

Perumahan dan pemukiman sebagai kebutuhan dasar, tidak hanya dapat dilihat sebagai sarana kebutuhan hidup, tetapi lebih dari itu merupakan proses bermukim manusia. Undang-Undang Dasar Negara Republik Indonesia Tahun 1945 menyatakan bahwa "Setiap orang berhak hidup sejahtera lahir dan batin, bertempat tinggal, dan mendapat lingkungan hidup yang baik dan sehat serta berhak memperoleh layanan kesehatan." Hal ini wajib dihormati, dilindungi, ditegakan dan dimajukan oleh pemerintah.

Pemerintah dalam memajukan kesejahteraan masyarakat khususnya berkenaan dengan tempat tinggal atau hunian mengembangkan suatu konsep pembangunan perumahan yang disebut dengan Rumah Susun. Rumah susun merupakan perumahan dengan sistem lebih dari satu lantai yang berarti perumahan yang dibagi atas bagian-bagian yang dimiliki bersama dan satuansatuan yang masing-masing dimiliki secara terpisah untuk dihuni, dengan memperhatikan faktor sosial budaya yang hidup di masyarakat. Rumah susun 
dibangun untuk mengantisipasi kebutuhan akan perumahan, terutama bagi golongan masyarakat menengah kebawah dan mereka yang berpenghasilan rendah.

Permasalahan yang terjadi bahwa para pelaku usaha dari rumah susun seringkali melakukan tindakan yang melanggar hukum misalnya tidak memberikan sertifikat hak milik atas satuan rumah susun (SHMSRS). Hal tersebut tentu berkaitan dengan hak seorang konsumen yang tidak diberikan oleh pelaku usaha sehingga melanggar ketentuan pasal-pasal yang terdapat dalam UndangUndang Perlindungan Konsumen No. 8 Tahun 1999.

Undang-Undang Perlindungan Konsumen dibentuk memiliki alasan dan tujuan untuk melindungi konsumen serta memberikan kepastian hukum agar terhindar dari tindakan sewenang-wenang pelaku usaha seperti yang terjadi pada penghuni Apartemen Kalibata City.

Penulis sebelum menganalisis kasus yang terjadi pada Apartemen Kalibata City maka pertama kali akan menjelaskan mengenai hubungan hukum yang terjadi antara pelaku usaha dengan warga Apartemen Kalibata City tersebut. Hubungan hukum yang melandasi hubungan antara pelaku usaha dengan warga kalibata city tersebut adalah hubungan hukum jual beli.Yang dimaksud dengan jual beli adalah suatu perjanjian bertimbal balik dalam mana pihak yang satu (penjual) berjanji untuk menyerahkan hak milik atas suatu barang, sedang pihak yang lainnya (pembeli) berjanji untuk membayar harga yang terdiri atas sejumlah uang sebagai imbalan dari perolehan hak milik tersebut. ${ }^{15)}$

Sesuai dengan pengertian jual beli diatas, maka dapat dilihat bahwa pihak yang bertindak sebagai penjual dalam hubungan hukum yang terjadi antara pihak pengembang apartemen kalibata city dengan para warga apartemen kalibata city, adalah pihak pengembang apartemen kalibata city itu sendiri. Sementara itu yang bertindak sebagai pembeli adalah para warga kalibata city. Selanjutnya dalam hubungan jual beli antara pihak apartemen kalibata city dengan para warga kalibata city, yang menjadi objek dari perjanjian jual beli tersebut adalah sertifikat hak milik satuan rumah susun (SHMSRS).

\footnotetext{
${ }^{15)}$ Subekti, Aneka Perjanjian, (Bandung: Citra Aditya Bakti, 1995), hal.1.
} 
Penulis dalam melakukan penelitian telah melakukan wawancara kepada salah satu warga Apartemen Kalibata City yang bernama Jimi Wolla. Beliau menjelaskan bahwa kasus ini telah terjadi cukup lama dari tahun 2009 sejak transaksi jual beli dilakukan. Pengembang Apartemen Kalibata City tidak memberikan hak legalitas para warga Apartemen yaitu Sertifikat Hak Milik Atas Satuan Rumah Susun (SHMSRS). Pak Jimi Wola sebagai salah satu penghuni merasa sangat dirugikan karena semenjak beliau melunasi Apartemen yang dimilikinya belum kunjung mendapatkan SHMSRS beserta dengan akta jual beli dari pihak pengembang Apartemen Kalibata City. Beliau telah mengupayakan beberapa cara agar mendapatkan haknya seperti mendatangi bagian legal dari pihak pengembang namun jawaban yang diterima selalu saja sama yaitu masih dalam proses oleh pihak Badan Pertanahan Nasional (BPN). Beliau memberi informasi bahwa pada tahun 2016, para penghuni Apartemen Kalibata City mendapatkan undangan dari pihak pengembang untuk menyelesaikan permasalahan yang terjadi dan berjanji akan mengurusnya tetapi undangan tersebut diberikan melalui group whatsapp sehingga para penghuni yang tidak berada di dalam group tidak mengetahui tentang undangan tersebut. Undangan tersebut berisikan persyaratan yang harus dipenuhi oleh para penghuni untuk mendapatkan hak mereka dan jangka waktu batas akhir pemberiannya. Namun pihak warga apartemen kalibata city banyak yang tidak setuju dengan biaya yang harus dikeluarkan untuk mengurus sertifikat hak milik satuan rumah susun tersebut. Beliau mengatakan bahwa warga bukan tidak mau membayar biaya administrasinya, tetapi warga hanya menuntut biaya yang wajar dikarenakan kenaikkan harga yang diberikan sangat besar yaitu 10 kali lipat daripada seharusnya. Selain itu, hal ini disebabkan oleh keterlambatan pihak pengembang dalam mengurus sertifikat hak milik satuan rumah susun bukan kesalahan para penghuni atau para warga Apartemen Kalibata City.

Beliau juga menjelaskan bahwa pihak pengembang Apartemen Kalibata City akan memberikan denda kepada warga yang telat melengkapi data dan mendatangani seluruh dokumen yang dibutuhkan dalam pengurusan sertifikat hak milik satuan rumah susun sebesar Rp. 750.000/bulan untuk pengecekan sertifikat dan Rp. 2.000.0000/bulan untuk penyimpanan sertifikat. Hal ini telah 
bertentangan dengan Pasal 1320 KUHPer mengenai syarat sah nya sebuah perjanjian.

Penulis melakukan wawancara berikutnya dengan Pak Robert, beliau adalah perwakilan dari Kementerian Pekerjaan Umum dan Perumahan Rakyat. Beliau menjelaskan bahwa kasus yang terjadi pada Apartemen Kalibata City sudah pernah diadukan kepada pihak Kementerian Pekerjaan Umum dan Perumahan Rakyat oleh perwakilan masyarakat Apartemen Kalibata City, mereka menuntut hak legalitasnya kepada pihak pengembang Apartemen Kalibata City namun sampai sekarang hak tersebut belum mereka dapatkan. Para warga juga mengadukan bahwa kemungkinan sertifikat hak milik atas satuan rumah susun tersebut diagungkan oleh pihak pengembang, sehingga sertfikat hak milik atas satuan rumah susun tersebut tidak dapat diberikan kepada para penghuni Apartemen Kalibata City. Beliau menjelaskan bahwa peran pemerintahan pekerjaan umum dan perumahan rakyat dalam menangani kasus ini dengan melihat duduk perkara beserta peraturan yang ada, namun yang jadi permasalahannya bahwa tidak ada peraturan yang mengatur tentang batas waktu pemberian sertifikat hak milik atas satuan rumah susun, sehingga pihak kementerian pekerjaan umum dan perumahan rakyat hanya mengusahakan pemerintah daerah dan pengembang Apartemen Kalibata City dapat segera melakukan kewajibannya dengan menyerahkan sertifikat hak milik atas satuan rumah susun kepada seluruh penghuni Apartemen Kalibata City. Pihak Kementerian pekerjaan umum dan perumahan rakyat juga telah mengadakan pertemuan antara pihak pengembang dengan para penghuni untuk memecahkan permasalahan yang ada. Hasil pertemuan tersebut adalah pihak pengembang yaitu PT. Pradani baru melengkapi persyaratan administrasi pengurusan sertifikat hak milik atas satuan rumah susun itu menjelang akhir tahun 2016 sehingga sertifikat baru dapat diterbitkan oleh Badan Pertanahan Nasional pada awal 2017, artinya keterlambatan sertifikat hak milik atas satuan rumah susun tersebut membuat membengkaknya biaya pengurusan dikarenakan nilai jual objek pajak pada awal warga membeli apartemen dengan sekarang sudah berbeda. Perbedaannya mencapai 10 kali lipat lebih tinggi. Pihak Kementerian Pekerjaan Umum dan Perumahan Rakyat menjelaskan bahwa keterlambatan pihak pengembang dalam 
melengkapi persyaratan administrasi yang mengakibatkan membengkak biaya pengurusan tidak boleh dibebankan kepada para warga Apartemen Kalibata City melainkan sudah menjadi tanggung jawab dari pihak pengembang.

Berdasarkan uraian fakta hukum dan hasil wawancara yang telah dijelaskan dalam BAB III serta berdasarkan hasil analisis bahan-bahan hukum yang dilakukan oleh penulis, bahwa tindakan pengembang apartemen kalibata city yang tidak memberikan hak milik satuan rumah susun, dapat dikatakan telah melanggar ketentuan dalam Undang-undang Rumah Susun dan Undang Undang Perlindungan Konsumen, hal ini dapat diurakan sebagai berikut:

a. Pasal 47 ayat (2) Undang-Undang Rumah Susun.

SHM sarusun sebagaimana dimaksud pada ayat (1) diterbitkan bagi setiap orang yang memenuhi syarat sebagai pemegang ha katas tanah.

Konsumen yang telah memenuhi syarat sebagai pemegang hak atas tanah berhak mendapatkan sertifikat hak milik satuan rumah susun. Namun, pada kenytaannya yang terjadi pada apartmen kalibata city bahwa pihak pengembang tidak kunjung memberikan sertifikat hak milik satuan rumah susun padahal mereka telah memenuhi syarat-syarat yang telah di tentukan oleh pengembang. Pihak konsumen apartemen kalibata city selalu meminta agar sertifikat hak milik satuan rumah susun yang menjadi hak mereka untuk segera diberikan tetapi jawaban pihak pengembang selalu sama yaitu mengatakan bahwa sertifikat hak milik satuan rumah susun yang mereka minta sedang dalam proses penerbitan oleh badan pertanahan nasional, konsumen apartemen kalibata city sudah sejak awal yaitu pada tahun 2009 telah memenuhi semua syarat tetapi sampai pada saat ini tahun 2018 sertifikat hak milik satuan rumah susun itu pun belum diberikan oleh pengembang.

Dengen demikian PT Pradani Sukses Abadi (PT Agung Podomoro Land) selaku pengembang telah melanggar ketentuan Undang-Undang Rumah Susun pasal 47 ayat (2). Dan harus segera memberikan sertifikat hak milik satuan rumah susun kepada seluruh konsumen apartemen kalibata city yang telah memenuhi persyaratan yang diberikan.

b. Pasal 4 huruf b Undang-Undang Perlindungan Konsumen. 
Hak untuk memilih barang dan/jasa serta mendapatkan barang dan/jasa tersebut sesuai dengan nilai tukar dan kondisi serta jaminan yang dijanjikan.

Setiap konsumen berhak mendapatkan barang dan/atau jasa yang sudah di janjikan oleh pelaku usaha sesuai dengan nilai tukar dan kondisi serta jaminan yang telah di janjikan oleh pelaku usaha. Namun, dalam kenyatanya yang terjadi pada apartemen kalibata city bahwa pihak pengembang tidak memberikan sertifikat hak milik satuan rumah susun pada sebagian besar penghuni apartemen kalibata city.Penghuni yang tidak memiliki sertifikat hak milik satuan rumah susun sudah berupaya untuk menuntut hak mereka sebagai konsumen. Salah satu upaya yang telah penghuni lakukan adalah degan cara, misalnya mereka sudah meminta kepada pihak pengembang dan melaporkan kejadian ini beberapa kali kepada kementrian pekerjaan umum dan perumahan rakyat tetapi sampai pada saat ini sebagian besar penghuni apartemen kalibata city belum juga mendapatkan hak mereka. Maka menurut penulis, Hal ini telah melanggar ketentuan dalam pasal 4 huruf $b$ Undang-undang perlindungan konsumen.Pelaku usaha dalam hal ini pengembang seharusnya sudah memberikan sertifikat hak milik satuan rumah susun yang telah dijanjikan sejak setelah konsumen melunasi kewajibannya yaitu membayar sesuai yang telah disepakati.karena setiap pemilik apartemen wajib memeilik sertifikat hak milik satuan rumah susun sebagai bukti atas kepemilikan suata unit rumah susun (apartmen). Hal ini juga ditegaskan dalam Undang-undang rumah susun pasal 47 ayat (2) yang berisi "SHM sarusun sebagaimana dimaksud dalam ayat (1) diterbitkan bagi setiap orang yang memenuhi sebagai syarat sebagai pemegang ha katas tanah". Pihak kementrian pekerjaan umum dan perumahan rakyat juga sudah berkali-kali di setiap kesempatan apabila bertemu dengan pihak PT Pradani sukses abadi (Agung Podomoro Land) selaku pengembang meminta agar segera memberikan hak-hak yang memang seharusmya di terima oleh warga apartemen kalibata city selaku konsumen. Teguran juga sudah dilakukan oleh pemerintah daerah kepada pihak pengembang agar segera memberikan hak-hak yang diminta oleh konsumen apartemen kalibata city. Tetapi sampai pada saat ini konsumen apartemen kalibata city belom juga mendapatkan apa yang menjadi hak nya setelah 
mereka melakukan kewajibannya sebagai konsumen. Pihak pengembang seakan-akan tidak menggubris aturan-aturan yang berada dalam undangundang perlindungan konsumen dan teguran yang telah diberikan oleh pihak kementrian pekerjaan umum dan perumahan rakyat dan juga oleh pemerintah daerah.

Dengan demikian bahwa PT Pradani Sukses Abadi (PT Agung Podomoro Land) selaku pengembang telah melanggar ketentuan yang terdapat dalam pasal 4 huruf $\mathrm{b}$ undang-undang perlindungan konsumen. Dikarenakan, pihak pengembang tidak memberikan hak konsumen sesuai apa yang telah diperjanjikan.

c. Pasal 4 huruf c Undang-Undang Perlindungan Konsumen.

Hak atras informasi yang benar, jelas, dan jujur mengenai kondisi dan jaminan barang dan/atau jasa.

Setiap konsumen berhak atas informasi yang benar, jelas, dan jujur mengenai kondisi dan jaminan barang dan/atau jasa yang diberikan oleh pelaku usaha. Namun pada kenyataannya yang terjadi pada apartemen kalibata city bahwa pihak pengembang apartemen bertentangan dengan ketentuan dalam pasal ini, dikarenakan pihak pengembang tidak secara benar dan jelas meberikan informasi mengenai kondisi atas sertifikat hak milik satuan rumah susun apartemen kalibata city pada saat ini. Dari awal terbentuknya apartmen kalibata city pihak pengembang selalu mengatakan bahwa sertifikat hak milik satuan rumah susun sudah dalam proses pengerjaan tetapi pada kenyataannya yang terjadi sampai saat ini, sudah lebih dari 7 tahun sertifikat hak milik satuan rumah susun tersebut belum juga diberikan oleh pihak pengembang, tidak sekali atau dua kali pihak konsumen apartemen kalibata city menanyakan menganai sertifikat hak milik rumah susun yang seharusnya sudah didapatkan setelah semua persyaratan telah dipenuhi, tetapi jawaban yang diberikan oleh pihak pengembang selalu sama yaitu sedang dalam proses oleh pihak badan pertanahan nasional.pihak pengembang selama ini selalu memberikan informasi yang menurut penghuni apartemen kalibata city tidak jelas dan tidak ada perkembangan sama sekali mengenai proses penerbitan sertifikat hak milik satuan rumah susun apartemen kalibata city. Dengan kata 
lain berarti pihak pengembang tidak jelas dan tidak jujur dalam memberikan suatu informasi kepada pihak konsumen apartemen kalibata city mengenai sertifikat hak milik satuan rumah susun yang telah lama diminta oleh penghuni.

Pihak pengembang juga tidak jujur dalam memberikan informasi atas perkembangan penerbitan sertifikat hak milik satuan rumah susun.karena baru diketahui selama ini pihak pengembang tidak memproses penerbitan sertifikat hak milik satuan rumah susun tersebut dan baru saja melakukan proses pengurusannya kepada pihak badan pertanahan nasional pada akhir tahun 2016. Padahal pihak konsumen sudah meminta sertifikat hak milik satuan rumah susun tersebut dari awal terbentuknya apartemen kalibata city dan setiap kali ditanya pihak pengembang mengatakan bahwa sertifikat hak milik satuan rumah susun itu sudah sedang dalam proses oleh pihak badan pertanahan nasional. Dalam hal ini pihak pengembang sudah tidak jujur atas informasi mengenai kejelasan sertifikat hak milik satuan rumah susun yang diberikan kepada pihak konsumen.

Dengan demikian bahwa PT Pradani Sukses Abadi (PT Agung Podomoro Land) selaku pengembang telah melanggar ketentuan yang terdapat dalam pasal 4 huuf c undang-undang perlindungan konsumen. dikarenakan, pihak pengembang tidak memberikan hak konsumen berupa informasi yang benar, jelas, dan jujur mengenai suatu barang dan/atau jasa,

d. Pasal 4 Huruf d Undang-Undang Perlindungan Konsumen.

Hak untuk didengar pendapat dan keluhannya atas barang dan/atau jasa yang digunakannya.

Setiap konsumen berhak didengarkan pendapat dan keluhannya atas barang dan/atau jasa yang digunakannya oleh pelaku usaha.Namun pada kenyataan yang terjadi bahwa pihak pengembang apartemen kalibata city telah melanggar ketentuan dalam pasal ini dikarenakan keluhan-keluhan yang di ajukan oleh pihak konsumen apartemen kalibata city atas kelalaian yang dilekukan oleh pihak pengembang seakan hanya dijadikan angin lalu.pihak pengembang apartemen kalibata city tidak pernah benar-benar mempedulikan atas keluhan-keluhan yang disampaikan oleh konsumen, hal ini dibuktikan 
dengan tidak diberikannya sertifikat hak milik satuan rumah susun apartemen kalibata city dengan tepat waktu. Padahal konsumen apartemen kalibata city sudah sering mengeluhkan tentang hal itu kepada pihak pengembang, akan tetepi pihak pengembang apartemen kalibata city seakan-akan tidak mendengarkannya. Sudah 7 tahun sejak apartemen kalibata city ini berdiri keluhan konsumen tetap sama yaitu meminta agar pihak pengembang memberikan sertifikat hak milik satuan rumah susun. Pihak konsumen apartemen kalibata city beranggapan bahwa pihak pengembang hanya mendengarkan saja tetapi mereka tidak dengan benar mengatasi masalah yang dikeluhkan oleh konsumen.

Selain keluhan atas sertifikat hak milik satuan rumah susun yang tak kunjung diberikan oleh pihak pengembang ada juga keluhan lain mengenai tarif-tarif jasa yang ditetapkan oleh pihak pengembang dikawasan apartemen yang menurut warga sangat memberatkan. salah satu keluhannya yaitu mengenai tarif parkir apartemen yang di tetapkan oleh pihak pengembang. Pihak pengembang menentapkan tarif parkir dikarenakan bagian unit yang berada dilantai dasar apartemen dijadikan lahan bisnis oleh pihak pengembang. Tetapi tarif parkir yang ditetapkan oleh pihak pengembang dirasa membertkan konsumen apartemen dan pihak konsumen merasa kebijakan tersebut tidak adil, karena penghuni apartemen diharuskan membayarkan tariff parkir yang sama dengan para pengunjung toko-toko yang berada di lantai dasar apartemen kalibata city. Warga mengeluhkan hal tersebut dan meminta agar penghuni apartemen kalibata city mendapatkan tarif parkir yang berbeda dengan pengunjung toko dikarenakan beda kepentingan antara penghuni dengan pengunjung toko-toko tersebut. Tetapi sampai sekarang tarif tersebut juga belum dirubah oleh pihak pengembang, padahal warga sudah lama mengeluhkan tentang masalah ini kepada pihak pengembang.

Dengan demikian bahwa PT Pradani Sukses Abadi (PT Agung Podomoro Land) selaku pengembang telah melanggar ketentuan yang terdapat dalam pasal 4 huuf d undang-undang perlindungan konsumen. Dikarenakan, pihak 
pengembang sering sekali merasa cuek dan tidak mendengarkan keluhankeluhan yang sering disampaikan oleh konsumen apartement kalibata city.

e. Pasal 4 Huruf g Undang-Undang Perlindungan Konsumen.

Hak untuk diperlakukan atau dilayani secara benar dan jujur serta tidak diskriminatif.

Setiap konsumen berhak untuk dilayani secara benar dan jujur serta tidak diskriminatif oleh pelaku usaha.Namun pada kenyantaannya yang terjadi bahwa pelaku usaha dalam hal ini pengembang telah melanggar ketentuan dalam pasal ini, karena warga apartemen kalibata city selaku konsumen merasa tidak dilayani secara benar dan jujur oleh pihak pengembang.konsumen apartemen kalibata city merasa pihak pengembang tidak benar dalam melakukan perjanjian jual beli dikarenakan dalam perjanjian jual beli pihak pengembang mengatakan bahwa apabila konsumen sudah melunasi pembayaran yang ditentukan maka pihak pengembang akan memberikan sertifikat hak milik satuan rumah susun tetapi pada kenyataannya sampai pada saat ini pihak pengembang belum juga memberikan sertifikat hak milik rumah susun tersebut. Pihak konsumen juga merasa pihak pengembang tidak jujur atas ketaranga-keterangan yang diberikan oleh pihak pengembang mengenai kejalasan atas sertifikat hak milik satuan rumah susun.Pihak pengembang mengatakan kepada konsumen bahwa sertifikat hak milik satuan rumah susun sudah diurus sejak saat apartemen kalibata itu selesai dibangun tetapi pada kenyataannya sertifikat hak milik satuan rumah susun itu baru di urus oleh pihak pengembang kepada badan pertanahan nasioanal pada akhir tahun 2016.

Dengan demikian bahwa PT Pradani Sukses Abadi (PT Agung Podomoro Land) selaku pengembang telah melanggar ketentuan yang terdapat dalam pasal 4 huuf g undang-undang perlindungan konsumen. Dikarenakan, pihak konsumen merasa tidak diperlakukan secara jujur oleh pihak pengembang.

f. Pasal 7 Huruf b Undang-Undang Perlindungan Konsumen.

Memberikan informasi yang benar, jelas, dan jujur mengenai kondisi dan jaminan barang dan/atau jasa serta memberikan penjelasan penggunaan, perbaikan dan pemeliharaan. 
Setiap pelaku usaha wajib memberikan informasi yang benar, jelas, dan jujur mengenai kondisi dan jaminan barang dan/atau jasa serta memberikan penjelasan penggunaan, perbaikan dan pe meliharaan kepada konsumen.pelaku usaha dalam hal ini PT Pradani Sukses Abadi (PT Agung Podomoro Land) tidak memberikan informasi yang jelas mengenai sertifikat hak milik satuan rumah ssun yang tidak kunjung diberikan kepada konsumen apartemen kalibata city. Pihak pengembang dari awal terbentukanya apartemen kalibata city selalu memberikan informasi bahwa sertifikat hak milik satuan rumah susun sudah dalam proses pengajuan kepada badan pertanahan nasional, tetapi pada kenyataannya seertifikat hak milik satuan rumah susun tersebut baru saja di ajukan kepada pihak badan pertanahan nasional pada akhir tahun 2016. Pihak pengembang jelas sudah melanggar ketentuan dalam pasal 4 huruf $\mathrm{b}$ undang-undang perlindungan konsumen, dikarenakan pihak pengembang sudah tidak jujur dalam memberikan informasi mengenai kondisi dan jaminan barang kepada konsumen apartemen kalibata city. Pihak pengembang dengam sengaja memberikan informasi yang tidak benar mengenai kondisi jaminan barang dalam hal ini sertifikat hak milik satuan rumah susun kepada penghuni apartemen kalibata city. Pihak pengembang dalam setiap menjawab pertanyaan mengenai kapan akan diberikannya sertifikat hak milik satuan rumah susun yang disampaikan oleh penghuni apartemen kalibata city selalu saja mengatakan hal yang sama yaitu sedang dalam proses pengajuan kepada pihak badan pertanahan nasional.

Pihak pengembang juga tidak transfaran mengenai biaya pemeliharaan gedung apartemen kalibata city, Penghuni apartemen kalibata city menduga pihak pengembang sengaja memperlambat proses penerbitan sertifikat hak milik satuan rumah susun dikarenakan pihak pengembang mengambil keuntungan dari pengelolaan biaya pemeliharaan apartemen seperti, penyediaan air, listrik, air dan sebagainya. Selama ini PT Pradani Sukses Abadi (PT Agung Podomoro Land) selaku pengembang masih memegang hak atas pengelolaan apartemen kalibata city dikarenakan belum jelasnya perhimpunan pemilik dan penghuni satuan rumah susun, jadi pihak pengembanglah yang mengelola apartemen kalibata city tersebut.Dalam 
mengelola apartemen kalibata city warga merasa pihak pengembang tidak transfaran mengenai biaya-biaya yang di diberikan kepada warga.Warga apartemen kalibata city merasa pihak pengembang menjadikan pemeliharaan apartemen sebagai bisnis.

Dengan demikian bahwa PT Pradani Sukses Abadi (PT Agung Podomoro Land) selaku pengembang telah melanggar ketentuan yang terdapat dalam pasal 7 huuf $b$ undang-undang perlindungan konsumen. Dikarenakan, pihak pengembang tidak melaksanakan kewajibannya yaitu memberikan informasi yang benar, jelas, dan jujur mengenai suatu barang dan/atau jasa,

g. Pasal 7 huruf g Undang-Undang Perlindungan Konsumen.

Memberikan kompensasi, ganti rugi dan/atau penggantian apabila barang dan/atau jasa yang diterima atau dimanfaatkan tidak sesuai dengan perjanjian.

Dalam pasal ini dijelaskan bahwa setiap pelaku usaha wajib memberikan kompensasi, ganti rugi dan/atau penggantian apabila barang dan/atau jasa yang diterima atau dimanfaatkan tidak sesuai dengan perjanjian kepada konsumen. Pelaku usaha dalam hal ini PT Pradani Sukses Abadi (PT Agung Podomoro Land) tidak memberikan ganti rugi terhadap warga apartemen kalibata city yang tidak mendapatkan apa yang sudah dijanjikan saat proses jual beli apartemen berlangsung. Pihak pengembang menjanjikan akan memberikan sertifikat hak milik satuan rumah susun setelah konsumen melunasi pembayaran unit apartemen tetapi pada kenyataannya yang terjadi hingga saat ini pihak pengembang tidak kunjung memberikan sertifikat hak milik satuan rumah susun sesuai apa yang dijanjikan dalam proses jual beli tersebut. Pihak pengembang juga tidak ada etikad baik untuk memberikan ganti rugi kepada konsumen apartement kalibata city atas kelalaian yang sudah dilakukannya, padahal dalam hal ini pihak konsumen apartement kalibata city tidak menerima barang yang telah dijanjikan oleh pihak pengembang sesuai dengan apa yang telah mereaka sepakati.

Dengan demikian bahwa PT Pradani Sukses Abadi (PT Agung Podomoro Land) selaku pengembang telah melanggar ketentuan yang terdapat dalam pasal 7 huruf g undang-undang perlindungan konsumen. Dikarenakan, pihak 
pengembang tidak melaksanakan kewajibannya yaitu memberikan kompensisa ganti rugi terhadap apa yang sudah dijanjikan.

\section{Penutup}

\section{A. Kesimpulan}

Berdasarkan pembahasan yang dipaparkan pada BAB IV, Penulis dapat menarik kesimpulan sebagai berikut:

Pelaku usaha dalam hal ini PT Pradani Sukses Abadi (PT Agung Podomoro Land) menjalankan kegiatan usahanya yaitu menjual unit apartemen dikawasan jakarta selatan yang bernama apartement kalibata city telah melanggar beberapa ketentuan hukum yang berlaku, antara lain pasal 4 dan pasal 7 Undang-Undang perlindungan Konsumen dan pasal 47 ayat (2) Undang-Undang Rumah Susun.

Pihak Pengembang telah dengan sengaja tidak memberikan hak konsumen kepada para penghuni apartemen kalibata city berupa sertifikat hak milik satuan rumah susun. Pihak pengembang beralasan bahwa sertifikat hak milik satuan rumah ssun yang selama ini diminta oleh penghuni apartement sedang dalam proses pembuatan oleh pihak badan pertanahan nasional, akan tetapi setalah dilakukan penelitian sertifikat hak mlik satuan rumah susun tersebut pihak pengembang baru melengkapi persyaratan administrasi pada akhir tahun 2016 dan sertifikat hak milik satuan rumah susun tersebut baru bisa diterbitkan pada tahun 2017. Artinya keterlambatan pemberian sertfikat hak milik satuan rumah susun tersebut dikarenakan terlambatnya pihak pengembang melengkapi persyaratkan administasi yang sudah ditetapkan sebagai syarat pengurusan sertifikat hak milik satuan rmah susun. Pihak pengembang pun tidak secara transfaran memberikan informasi mengenai sertifikat hk milik satuan rumah susun tersebut, sehingga banyak warga yng tidak mendapatkan hak nya disebabkan kurangnya informasi yang diberikan oleh pihak pengembang kepada konsumen untuk melengkapi persyaratan-persyaratan yang harus dipenuhi agar sertifikat hak milik satuan rumah susun mereka dapat di proses. 


\section{B. Saran}

Berdsarkan kesimpulan yang telah disebutkan sebelumnya, Penulis memaparkan saran sebagai berikut:

1. Pelaku Usaha dalam hal ini PT Pradani Sukses Abadi (PT Agung Podomoro Land) harus segera memberikan hak-hak konsumen apartement kalibata city sesuai apa yang sudah diperjanjikan sejak awal terjadinya suatu transaksi jual beli apartement agar penghuni apartemen kalibata city selaku konsumen merasa diharga. Pihak pengembang juga seharusnya memberikan informasi yang sejelas-jelasnya mengenai kondsi suatu brang dan/atau jasa agar dikedepannya tidak ada lagi kesalahan pahaman antara pihak pengembang dan konsumen apartement kalibata city dikemudian hari.

2. Pemerintah seharusnya ikut serta secara langsung untuk menyelesaikan kasus ini yang sudah berlangsung cukup lama dan belum selesai sampai pada saat ini. Pemerintah juga seharusnya memberikan sebuah sanksi yang tegas terhadap PT Pradani Sukses Abadi (PT Agung Podomoro Land) selaku pihak pengembang yang tidak kunjung memberikan sertifikat hak milik satuan rumah susun agar tidak terjadi lagi kepada pengembangpengembang lainnya yang secara sengaja memperlambat pemberian sertifikat hak milik satuan rumah susun.

3. Dibuatnya undang-undang yang mengatur secara jelas mengenai sertifikat hak milik satuan rumah susun dan pemberian sanksi-sanksi apabila ada pihak-pihak yang dengan sengaja melanggar peraturan yang tercantum didalamnya.

\section{DAFTAR PUSTAKA}

\section{A. Buku}

Badan Pertanahan Nasional. Himpunan Karya Tulis Pendaftaran Tanah. (Jakarta, 1989).

Harsono, Boedhi. Hukum Agraria Indonesia. Cetakan ke-9. (Jakarta: Djambatan, 2003). 
Marzuki, Peter Mahmud. Penelitian Hukum Edisi Revisi. Cetakan ke- 8. (Jakarta: Kencana Prenada Media Group, 2013).

Rosmidi, Mimi dan Imam Koeswahyono. Konsepsi Hak milik atas Satuan Rumah Susun dalm Hukum Agraria. (Malang: Setara Press, 2010).

Sarkawi. Hukum Pembebasan Tanah Milik Adat Untuk Pembangunan Kepentingan Umum. Cetakan Ke-1. (Yogyakarta: Graha Ilmu, 2014).

Subekti, Aneka Perjanjian, (Bandung: Citra Aditya Bakti, 1995).

Soekanto, Soerjono dan Sri Mamudji. Penelitian Hukum Normatif Suatu Tinjauan Singkat. (Jakarta: Raja Grafindo Persada, 2009).

\section{B. Peraturan Perundang-Undangan}

Indonesia. Undang-Undang Dasar Negara Republik Indonesia Tahun 1945. Pasal 28 Ayat 1.

Indonesia. Undang-Undang Nomor 20 Tahun 2011 tentang Rumah Susun. (Lembaran Negara Republik Indonesia Nomor 108). Pasal 1 angka (1).

Indonesia. Undang-Undang Nomor 39 Tahun 1999 tentang Hak Asasi Manusia (Tambahan Lembaran Negara Republik Indonesia Nomor 3886). Pasal 40.

Indonesia. Undang-undang Nomor 8 Tahun 1999 tentang perlindungan konsumen (Lembaran Negara Republik Indonesia Tahun 1999 Nomor 42, Tambahan Lembaran Negara Republik Indonesia Nomor 3821). Pasal 4. 